Mercator, Fortaleza, v. 16, e16025, 2017.

DOI: https://doi.org/10.4215/rm2017.e16025

ISSN: $1984-2201$

Copyright @ 2002, Universidade Federal do Ceará

\title{
THE CONTRIBUTION OF THE OLYMPIC GAMES TO BEIJING'S LEGACY
}

\author{
YAMAWAKI, Yumi a *
}

(a) Phd in Urbanism, Professor Federal Technological University of Paraná (UTFPR). http://lattes.cnpq.br/1944559624960051

\section{(*) CORRESPONDING AUTHOR}

Address: UTFPR, Rua Deputado Heitor Alencar Furtado, 4001, CEP: 81280340 - Curitiba (PR), Brasil. Tel: (+55 41) 32794500

E-mail: yumi.yamawaki@gmail.com

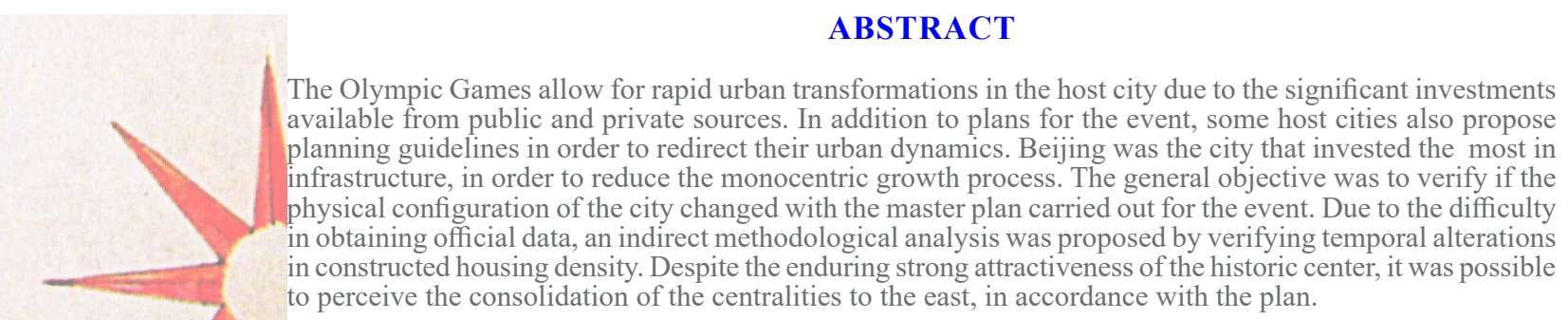

Keywords: Urban plans; Major sporting events; Olympic legacy.

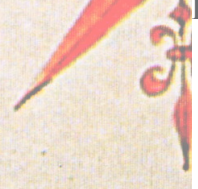

RESUMO/ RESUMEN

\section{CONTRIBUIÇÃO DOS JOGOS OLÍMPICOS PARA O LEGADO DE BEIJING}

Os Jogos Olímpicos oportunizam a implantação de rápidas transformações urbanas na cidade-sede em função dos significativos investimentos disponíveis de fontes públicas e privadas. Algumas sedes, propõe não somente planos para a realização do evento, mas diretrizes de planejamento com o intuito de redirecionar sua dinâmica urbana. Beijing foi a cidade que mais investiu em infraestrutura, com o intuito de reduzir o processo de crescimento monocêntrico. $\mathrm{O}$ objetivo geral foi verificar se a configuração física da cidade se modificou a partir do plano diretor realizado para o evento. Pela dificuldade de obtenção de dados oficiais, foi proposta uma metodologia indireta de análise por meio da verificação de alterações temporais de densidade habitacional construída. Apesar da permanência de forte atratividade do centro histórico, foi possível perceber a consolidação das centralidades à leste, conforme plano pretendia.

Palavras-chave: Planos urbanísticos; Grandes eventos esportivos; Legado olímpico.

\section{PLAN URBANISTICO DE BEIJING PARA LOS JUEGOS OLIMPICOS DE 2008}

Los Juegos Olímpicos promoven la aplicación de rápidas transformaciones urbanas en la ciudad anfitriona en función de las importantes inversiones disponibles a partir de fuentes públicas y privadas. Algunas sedes olímpicas, proponen no sólo los planes para el evento, pero directrices de planificación con la intencíon de redirigir sus dinámicas urbanas. Beijing fue la ciudad que más invirtió en infraestructura, con el fin de reducir el proceso de crecimiento monocéntrico. Debido la dificultad de obtener datos oficiales, se propuso una metodología indirecta de análisis mediante la comprobación cambios de densidad temporales de vivienda construidos. El objetivo fue verificar si la configuración física de la ciudad ha cambiado desde el plan maestro realizado para el evento. A pesar de la permanencia de fuerte atractivo del centro histórico, fue posible percibir la consolidación de las areas al este, conforme el plan pretendía.

Palabras clave: Planes urbanístico; Grandes eventos deportivos; Legado olímpico. 


\section{INTRODUCTION}

At the end of the twentieth century, the media began to play a fundamental role in the dissemination of ideas. Thompson (1998, p.106) highlights the importance of the media phenomena in the symbolic construction of modernity. The media is actively involved in building the social world. By bringing information to individuals living in different and distant contexts, the media models and influences the course of events, creating events that might not have existed in its absence. One form of exposure is the hosting of major international events. These attract a large number of sponsors who want to link their brands to the universal values advocated by the event. Consequently, holding them facilitates the implementation of rapid urban transformations, due to the financial resources made available by both the public and private sectors.

The Olympic Games elect a host city, resulting in a greater concentration of investments and urban interventions, which may accelerate preconceived directives or redirect the city planning process (Essex and Chalkley 1998, p.187). However, many of the cities that host this event have not been able to transform the temporary media exposure and the significant amount of resources into something positive and lasting locally for citizens.

In this context, the form of intervention in urban space has a significant social impact. However, discussions about the legacy of major sporting events occur mostly without empirical studies and under theoretical premises.

Therefore, the present article has a methodological focus, with the aim of supporting morphological studies in host cities of major events. Beijing, the host of the 2008 Olympic Games, was chosen as the object of analysis, since it was the city that invested the most in infrastructure. This study intends to analyze the intentions of the proposed planning, the consolidation process and whether physical-territorial changes actually occurred. Due to the difficulty in obtaining official data, it was necessary to elaborate a specific methodology of indirect analysis using aerial images.

The hypothesis that directed the research was that major sporting events can redirect the urban dynamics, if the host city delineates planning directives directed to itself, and not following possible urban models linked to the Olympic Games.

Therefore, the overall objective was to identify the physical dynamics in Beijing resulting from major urban projects by analyzing their effects on urban form and interpreting to what extent they benefit the local population in the long run.

The research was conducted establishing relations of spatial interventions with the social processes resulting from them, in order to help understand the impacts and benefits to the local community. That is to say, the object will always be the set of physical works carried out for the Olympic Games that aimed at some transformation of the larger urban context beyond the venues where the competitions took place.

The growing competitiveness between cities to host these major sporting events makes it important to discuss the urban development that occurs because of them.

\section{THEORETICAL FRAMEWORK}

The criteria used to analyze the areas occupied by urban agglomerations may be density, fragmentation, linearity and centrality. Density is the most used indicator and the result depends on the measurement of the area occupied in relation to the resident population (OJIMA, 2007).

However, there is no consensus on which density can be considered adequate for the different typologies of use (TORRENS, ALBERTI, 2000). Therefore, it is difficult to measure what is considered urban sprawl. These large disparities and the different realities found in the world's cities induce the study of other forms of measurement. 
Torrens and Alberti (2000) indicate the analysis of the density gradient as an alternative. As the area moves away from the center, the density can gradually reduce, within attenuation parameters. The authors argue that, in this way, it is possible to infer not only the degree of density, but the changes over time, since dispersion and concentration are dynamic phenomena.

Fragmentation verifies whether there is contiguity in the occupation or whether there are leapfrogs, that is, urban masses arranged separately. Leapfrogs can result from the process of disconnection of spaces associated with changes in population movement flows, demonstrating that contiguity is no longer necessary for communication between the urban masses. The more dispersed they are, they can advance into agricultural and environmental areas and demand that the infrastructure addresses increasingly distant areas. Despite having pleasant effects, the vegetative cover of their interstices usually have reduced environmental results due to fragmentation.

According to Ojima (2007), linearity occurs when there are natural physical barriers (mountains, water courses) or manufactured ones (roads, railroads, economic poles) that promote growth. Therefore, there are differences in infrastructure services if areas of concentric growth and linear growth are compared.

Finally, centrality measures the level of polarization of the municipality. The greater the pendular movement, the more compact the municipality tends to be, occupying the fringes of the city-pole. On the contrary, the less dependent the city-pole, the more dispersed it tends to be. Therefore, dispersion is not always a negative factor of occupation.

These phenomena can be analyzed independently of the population size of each municipality, which makes it possible to verify them in the different host cities of the Olympic Games.

\section{METHOD OF ANALYSIS}

Holland (2011, p.21) emphasizes the importance of relational analysis between physical-spatial patterns and social expectations, since inattention to the multidimensional nature of spaces can lead to simplistic points of view that highlight problems and disregard qualities. For this reason, in order to verify if the purpose and manner of the master plan for the Beijing Olympic Games was fulfilled, emphasis was given to the physical ambit, but there was an attempt to establish correlations with the other dimensions of interpreting the urban proposed by Friedmann (2005, p.36): administrative, economic, sociocultural and political.

Preuss (2008) warns of the difficulty of separating the aspects that directly involve the Olympic Games and others. Therefore, the analysis was made with the intention of identifying urban transformations, without the commitment to establish to what extent they were related to the event itself. The years between the announcement and completion of the Olympic Games were used only as time references to check what happened before and after. This is justified because, according to Pitts and Liao (2009, p.23), it is not possible to establish a starting point or an end to the process of urban transformation linked to the Olympic Games.

Added to this, the context in which the event is inserted modifies the manner of planning and acting in a city. For this reason, there was a concern to contextualize the planning history and to cite cultural, political and ideological aspects that impact on the urban space and, from this, analyze the physical consolidation of the intervention master plan.

Beijing chose to build an Olympic Park that concentrated most of the sports structures. Soon after being chosen as the host for 2008, a master plan was drawn up in 2004 that contemplated not only compliance with the guidelines established by the International Olympic Committee (IOC), but also significant investments in infrastructure.

In this sense, Poynter (2008, p.83) has shown that the increase in the costs of organizing the Olympic Games are essentially due to the increase in investment in optional measures, which are fundamental to the viability of legacies (Preuss, 2008, p.83). 
The measurement of the Beijing legacy was restricted to 4 years, since the economic and morphological dynamics are quite pronounced, which accelerated the result of the impacts of the event. If the analysis considered a longer period, it would not be possible to identify the impacts related to the Olympic Games, since, as occurred in Barcelona (1996), a significant number of interventions were carried out after the event, which would jeopardize the evaluation.

The housing density was analyzed with the intention of verifying how this portion of space was configured over the years before and after the event. The population density could signal that the urban interventions carried out due to the city hosting the event were relevant in producing new centralities, which was one of the objectives of the 2004 Master Plan.

\section{BEIJING'S URBAN PLANNING}

It is evident that governmental centralism has always led the planning process of Chinese cities, subordinated to a macro-plan, which reflects the national strategies from feudalism to the present day, under communist rules.

The main characteristic of the spatial organization of the pre-Maoist period was the functional differentiation and land specialization, based on clans (Gaubatz, 1999, p.1497).

The history of Beijing's urban transformation has left its mark on the current structure of the city and can be summarized as follows: the central area of Beijing, where the old capital is located, was founded in 1267 and retains its characteristics, with a dense network of orthogonal routes regulated by the main axis and rectangular blocks.

Soon after the 1949 Revolution, the urban form - from the Maoist period - merges a new style of development with the traditional one. It is structured in isolated work units where a small community concentrates its work and leisure (Jun; Xiaoming, 2008, p.21).

The shape of the second ring follows the design of the walls demolished in the 1950s, and has the Imperial Palace in the center, opposite Tiananmen Square. Two north-south and east-west orthogonal axes demarcate four districts (Greco and Santoro, 2007, p.119).

Soviet style planning has forced the capital Beijing to become a productive, non-consumer city, with the deployment of large manufacturing areas. This occurs even when sheltering water sources and relevant mineral resources (Friedmann, 2005, p.11).

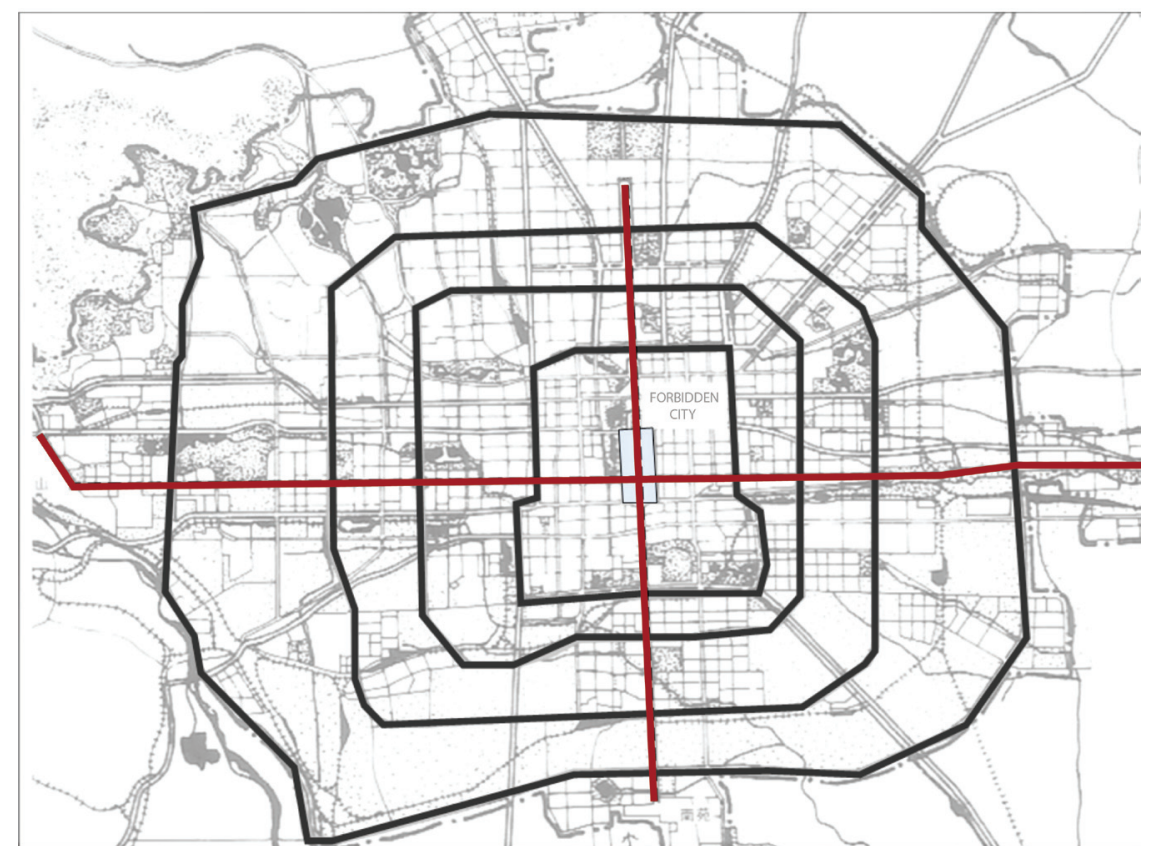

Figure 1 - Main road design of Beijing - 1982 Source: Wang, 2011. 
These differentiated regional policies - Ladder-Step Doctrine - have benefited coastal areas economically, with privileges regarding the deployment of infrastructure and human resources to accelerate and expand the industrial sector (Rong et al., 2008: 37). Beijing, which became directly administered by its State Council, had significant economic development.

From 1949 to 1960, there was a strong process of flow to the cities. This resulted in a government measure that distinguished the residence permit (hukou) between urban and rural citizens (Deng; Huang, 2003, p.212).

This prioritization of portions of space marks the need to rethink the transition between the city of capitalist consumption and the productive socialist one. To this end, in the 1970s the planners directed the plan to serve the tertiary sector.

The planning of the road system with a persistent reference to the center, where political power is concentrated, has been the fundamental principle determining the city's evolution (Greco and Santoro, 2007, p.119).

The 1992-2010 Regulatory Plan provided for the conservation of the historic center and the articulated growth of the sequential rings that concentrate most of the state's investments, while the peripheries were reformulated through private investments (Greco and Santoro, 2007, p.119). This fact, added to the process of industrialization of the city, fragmented the spatial configuration and resulted in the mixture of incompatible uses living side by side.

Heavy industries account for $63.7 \%$ of the city's economy, while housing issues have been neglected. Of all the existing buildings, only $40 \%$ were intended for housing. Of these, $80 \%$ were precarious bungalows in the city center (Wang, 2011).

According to the municipal planning body, Beijing needed to limit its area and proposed designating $614 \mathrm{~km} 2$ for buildings and the remainder maintained as a green reserve. The city still seeks its water resources within the territory of its jurisdiction (Wang, 2011, p.31).

The reading of Beijing's current landscape demonstrates predominant typologies: the ones delimited as SEZs (Special Economic Zones), with high multi-functional glazed skyscrapers; less structured areas with lower buildings with simpler architectural features, occupied by the population originating from rural areas (ViCs - Village in the City); and a third typology that are the single-floor houses with a quadrangle (siheyuans) and a grid of alleys for pedestrian movement only (hutongs). However, this configuration tends to persist only in the areas delimited as historical patrimony, due to the intense dynamics of current urban constructions.

The SEZs are areas where there is a concentration of infrastructure and flexibility of occupation due to reduced urban regulations aimed at attracting large foreign companies. (Friedmann, 2005).

The ViCs, consisting of six to eight-storey residential buildings, are juxtaposed occupations that are insalubrious, often without sanitary facilities and private kitchens, built by former farmers who rent their property to peasants without a residence permit in the city (Deng; Huang, 2004, Yan, 2008, p.56, Hassenpflug, 2010, p.124).

The relationship between the typologies presented and local power explain the rapid dynamics of Chinese real estate: the right to use the land is granted for a fixed period, both to ex-farmers and private developers, demanding speediness in the use of a property, with a view to profit (Greco and Santoro, 2007, p.159).

Gaining the right to host the Olympic Games in 2004 generated commitments to the IOC, which would require significant changes in the city as a whole. At that time, a master plan was elaborated that foresaw the preservation of the historical patrimony of the buildings arranged along the central axes and the intention to establish two belts: one ecological and one productive. The western portion would be reorganized according to environmental principles and the east was planned to serve as a production zone (Song et al, 2006). 


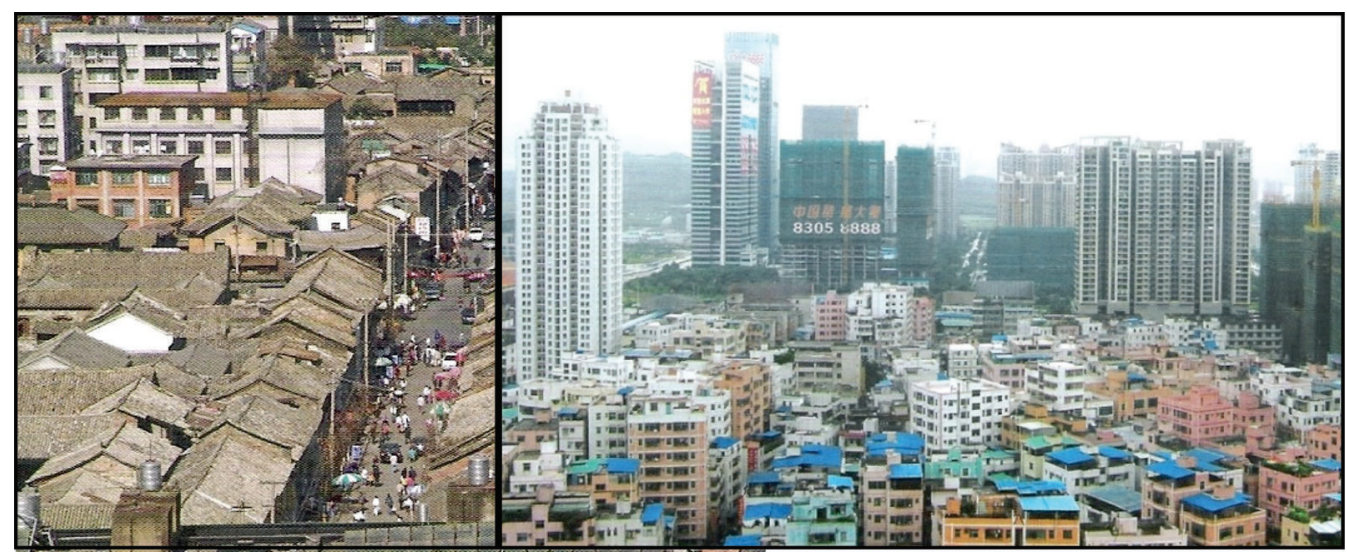

Figure 2 - Aerial image of a hutong and a ViC. Source: Jian, 2008; Yan, 2008.

The plan would encourage the formation of a multi-center system, consisting of SEZs: Haidian, the Central Business District (CBD), Sanlitun, the Northeast Area and the Airport Line, the Historic Center and the Olympic Green. Economically, the project can be considered a success, because currently $60 \%$ of the city's GDP comes from these areas (Greco and Santoro, 2007, p.120).

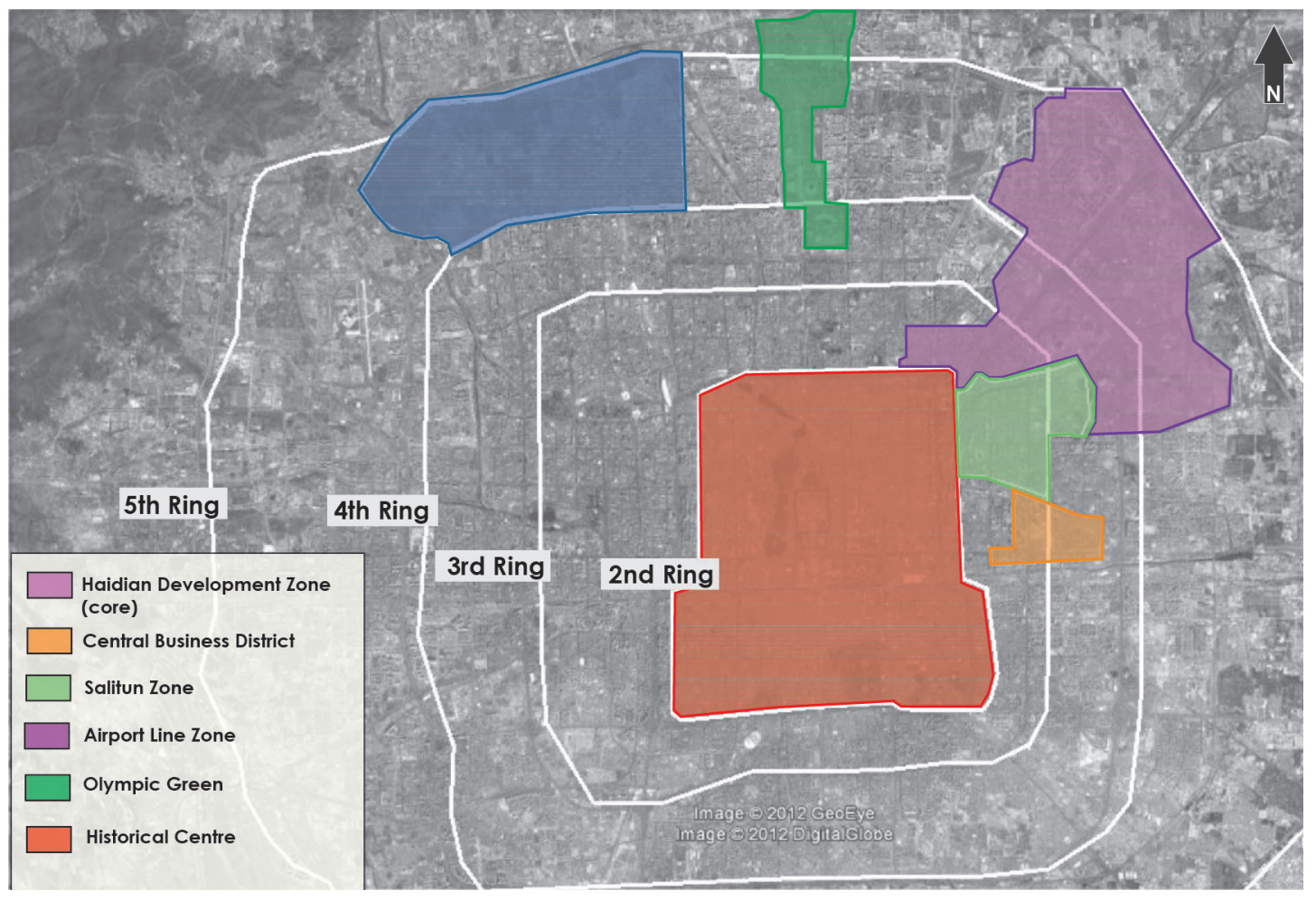

Figure 3 - Beijing's Special Economic Zones

Source: Greco and Santoro, 2007.

The CBD and Olympic Green are areas inspired by Western trends aimed at intensifying exchanges between member countries of the World Trade Organization. The public authorities intended to attract foreign entrepreneurs to China, with the implementation of several multi-functional complexes (Greco and Santoro, 2007, p.120).

Unlike Western CBDs, where there is only a concentration of enterprises, in Beijing they would function like the other development zones in the city, with mixed uses, so that the population that works in a location also resides and consumes there, consolidating it as a self-sufficient area (Greco and Santoro, 2007, p. 122). 
Between the CBD and the airport region is Sanlitun, a luxury residential district, which houses embassies and tourist-oriented bars.

The 20-km long expressway corridor connects Beijing's central area with the airport through the city's best constructed artery. According to Greco and Santoro (2007), the area is undergoing a revitalization process and cultural activities have been installed there.

The historic center, the portion that best represents the city's identity, currently has a third of its buildings preserved in a gradual process of demolitions and vertical construction, mainly in the 1960s, 1970s and 1980s (Yukata et al., 2004, p.196).

This plan demonstrated the impetus for renewal of local power, which resulted in the expansion of occupation into protected areas. The planning agencies of the districts began to approve large parks and areas of commerce and the extension and paving of priority roads, with a view to beautifying the city for the foreign tourists attracted to the event (Pitts; Liao, 2009, p.92).

Unlike locations like Barcelona, which atomized sports structures with the intention of producing improvements in the city as a whole, Beijing, given its scale (Greater Barcelona is 3,236 km², while Greater Beijing is $16,807.8 \mathrm{~km} 2$ ), could not use the same premise as the long distances between facilities would not meet the standards demanded by the IOC. Beijing proposed the construction of a specific park for the event and concentrated most competitions in a single space.

The Olympic Green, just one of the SEZs created by the master plan, demonstrates that the importance conferred on the Olympic Park by the city was less than in the previous host cities of the Olympic Games, where it was the main urban intervention in the period. Therefore, its position to the north, near the universities, the airport and other development areas, would produce mutual help towards the success of the decentralization plan.

This plan permits concentrating the infrastructure, commercializing this privileged space in a differentiated way and concentrating services and amenities for a socioeconomically homogeneous public. The intention of characterizing Beijing's urban development by polycentric dispersion began in 1958 and subsequently the plan was revised in 1983, 1993 and reaffirmed in 2004.

This study intends to verify to what extent the plan is consolidating, since this was the city's main urban purpose when drawing up the master plan of intervention to host the Olympic Games.

\section{CONSOLIDATION OF THE POLYCENTRIC CONFIGURATION}

This analysis aims to verify whether the SEZs have been physically consolidated and, if so, whether the urban interventions related to the Olympic Games could have assisted in this process. Due to the difficulty in obtaining official information, the proposed methodology uses indirect data that may aid in the analysis. In order to verify if there was a change in the housing density built due to the Olympic Games, the time cut of 2002 (the period prior to the choice of the host city) to 2012 (four years after the event) was established. Housing density was adopted as a proxy in the present research, since it is believed that this dynamic can physically demonstrate an intention to occupy the new centralities proposed by the 2004 Master Plan.

For this, orthogonal axes were traced, passing through the center of each SEZ.

Along these lines, areas of one hectare were subdivided for the number of households to be counted and a color scale was established; the darkest representing the highest densities.

If a building had more than one floor, each floor was considered a dwelling and the facades were checked using the Google app called Street View. The objective here was not an accurate measurement, but the verification of variations in the housing density in the proposed temporal cut. Therefore, the counting was performed visually.

The analyzes were carried out in the years 2002 or 2003 - according to the image available - and in 2012. Only the residential buildings were counted, since this use demonstrates that the population was opting for these areas to enjoy the structure made available by the public authorities. Housing use shows a greater degree of stability of the location, while other uses (mainly, commerce and 
services) are characteristically more mobile. In this sense, other uses or vacant lots were disregarded in the analysis, and those squares are shown in white.

It was assumed that if there were polarization of the SEZs, the color would intensify according to the established gradient as it approached these centralities. The maps show the location of the axes and the amplified schematics were deformed to improve the visualization of the color gradient.

In order to verify whether the density of the Olympic Green occurred differently from the other SEZs, the same methodological analysis was applied and eight-kilometer long orthogonal axes were traced from the central area of each compartment, attempting to cover the area occupied by the central rings.

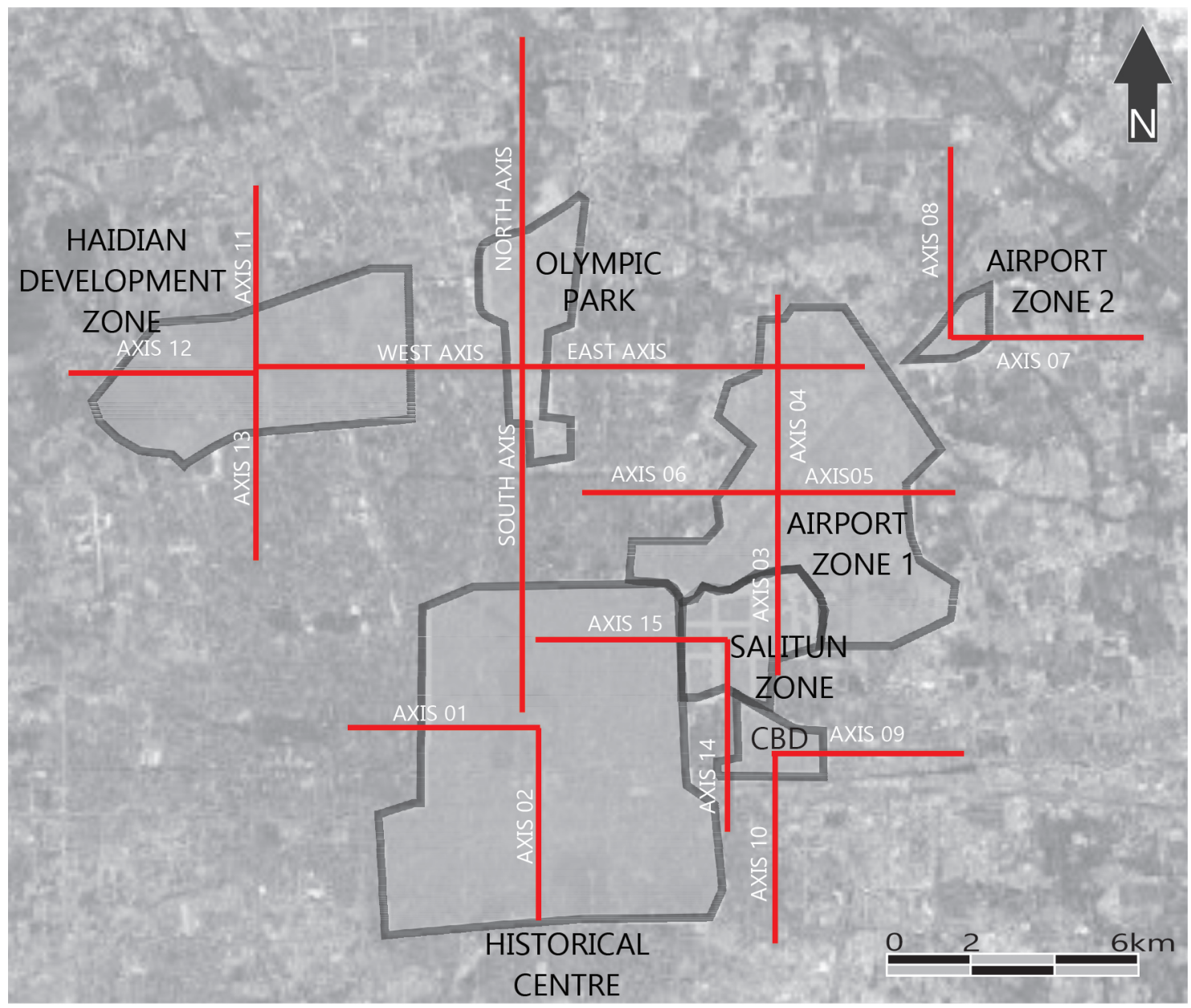

Figure 4 - Schematic of the analyzed axes Source: the author, 2013 and Google Earth cartographic base.

\section{ANALYSIS OF RESULTS}

Regarding the Olympic Green SEZ, the 2003 and 2012 schematics towards the north and south reveal that the process of construction of the Olympic Park did not produce significant densification effects in the surroundings. To the north, the presence of Forest Park and the fifth ring interrupts the connection with the existing occupations, besides sectioning the north-south axis of the city.

The southern portion is the direction more conducive to growth as it connects with the central area of the city, there is practically no change in the temporal cut analyzed. To the east and west, in 2003, there was already a dense occupation that was also relatively unchanged after the construction of the Olympic Park. However, it seems to become denser in the western portion, near the Olympic Village. 
The decision to locate sporting structures away from the city center can promote links between old and new areas through the development of a directed flow (Pitts; Liao, 2009, p.157). In the case of Beijing, four years after the end of the event, the zone demarcated as the Olympic Green does not have an intense densification process.
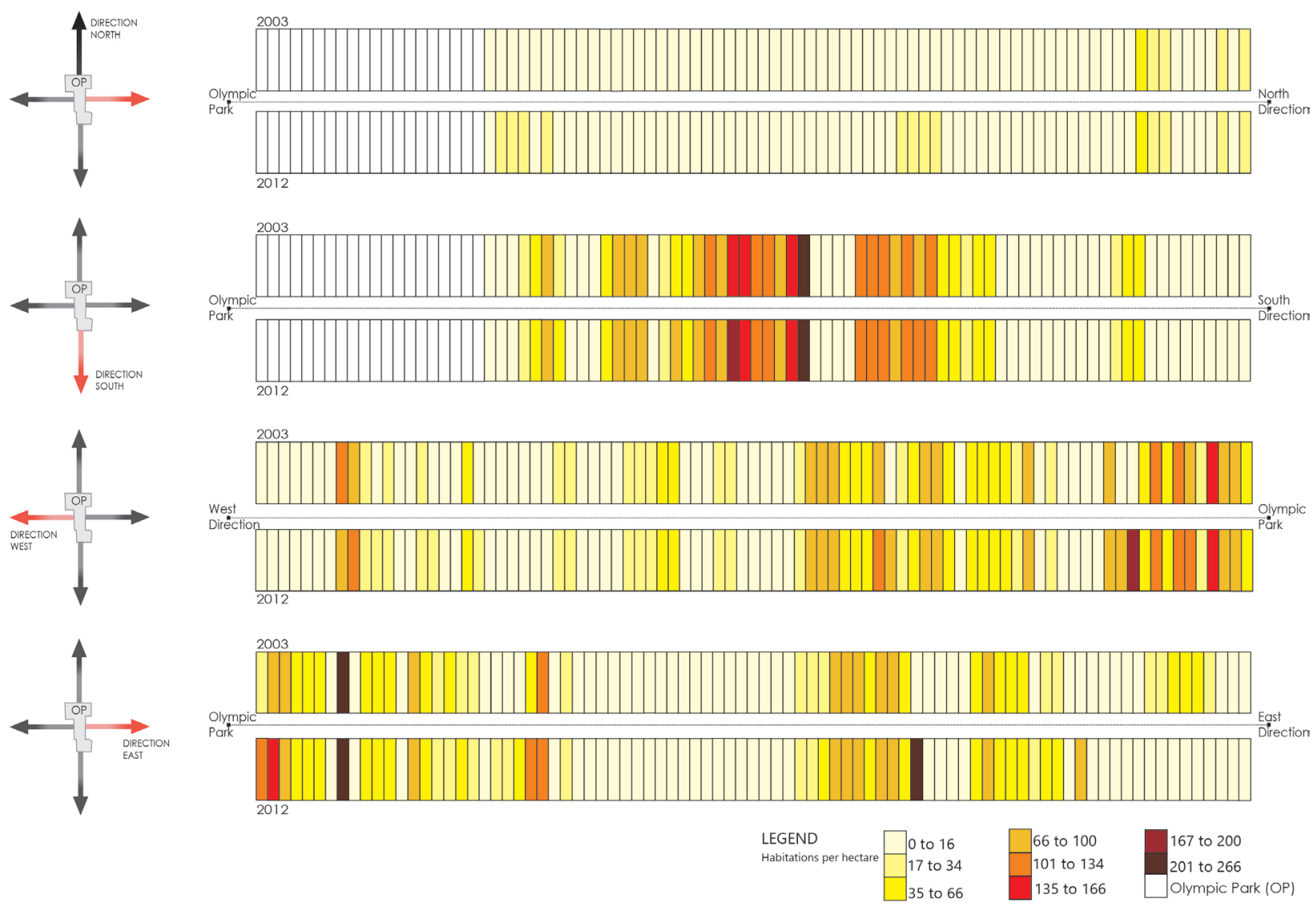

Figure 5 - Axes of the Olympic Green SEZ in 2003 and 2012 Source: the author, 2013 and Google Earth cartographic base.

Even with the proximity between the Haidian Development SEZ and the Olympic Green SEZ, these do not seem to connect, as the west axis of the Olympic Green reduces in density as it moves away from the Olympic Park and approaches the Haidian university area.

On axis 11 (north of Haidian), it is possible to verify minor modifications between 2002 and 2012, even around subway lines 4 and 13, both implemented in 2008. Axis 13 (south of Haidian) shows that the center of this compartment did not attract any population, since the southern end remains denser in 2012. However, it is possible to perceive the influence of the implementation of subway line 10, inaugurated in 2008, which presents a denser environment in 2012 than in 2002. 
AXIS 11

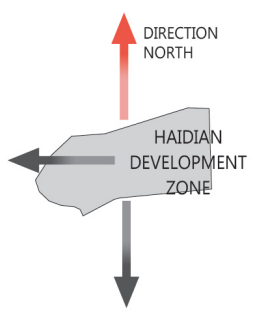

AXIS 13

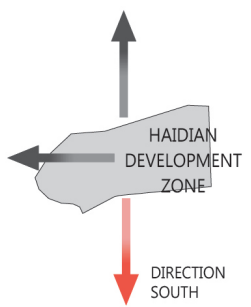

AXIS 12

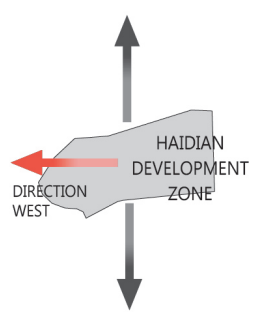

Obs: Starting point of the analysis:

Crossing between Zhongguancun St X Chengfu Rd

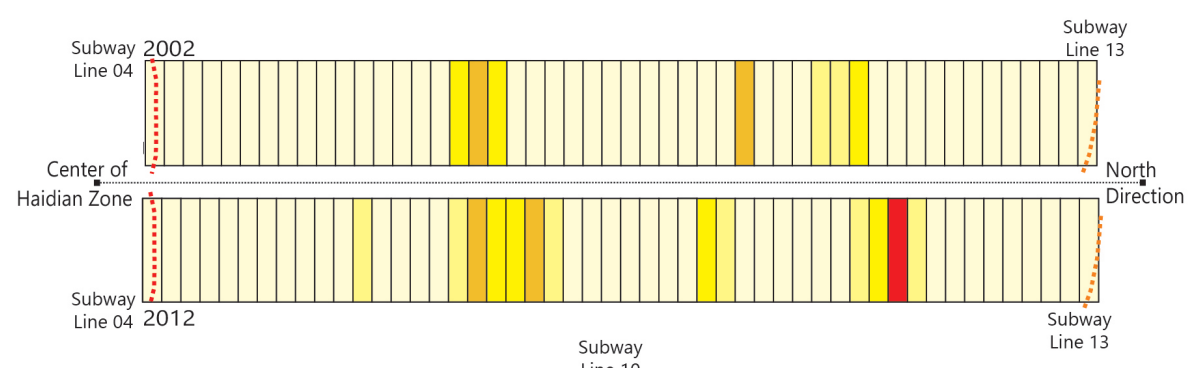

Subway
Line 10

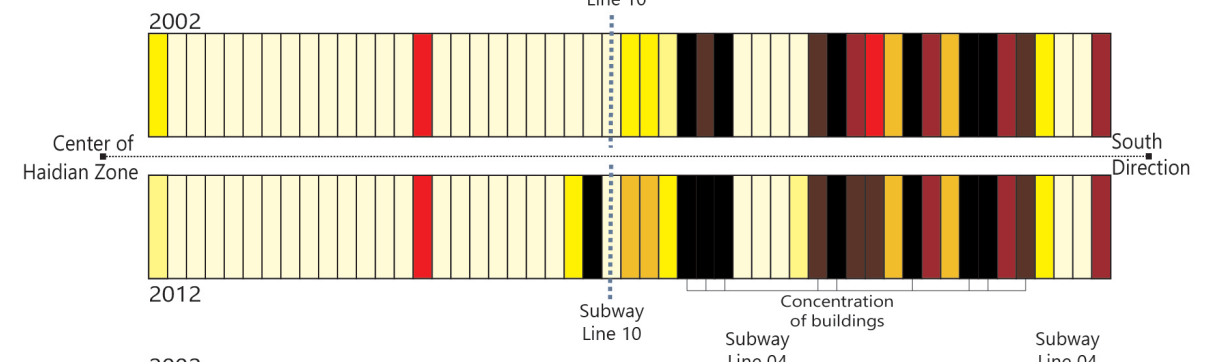

Line 04 04

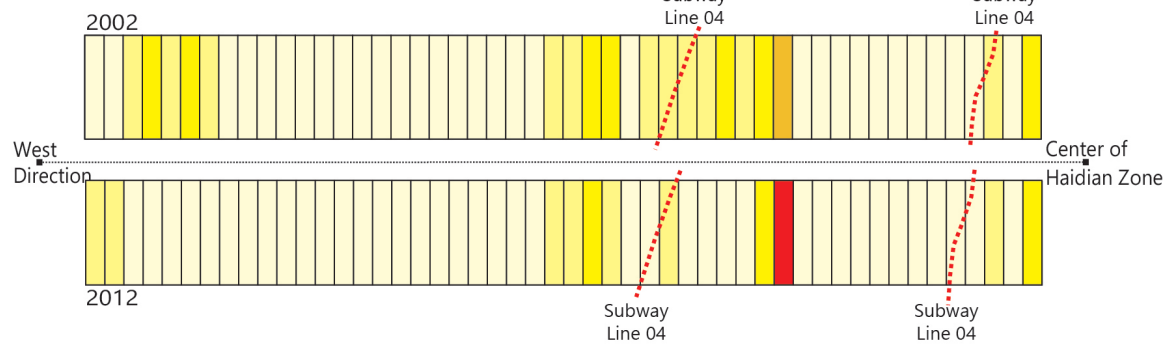

167 to 200
201 to 266
Above 266

Figure 6 - Intensification of the density of the Haidian Development Zone SEZ in 2002 and 2012 Source: author, 2013, and Google Earth and Google Street View cartographic base.

In the southern and northern portions (axes 3 and 4) of the Airport - 1 SEZ, the occupancy density was maintained and the proposed centrality did not attract significant residential population contingents.

On axis 6 (west of Airport Zone - 1), which approaches the Olympic Green SEZ, in 2012 there was a greater consolidation in portions outside the limits of the SEZs, places occupied by dense ViCs. In axis 5, the densities show an insignificant increase that approaches the center of this compartment. 


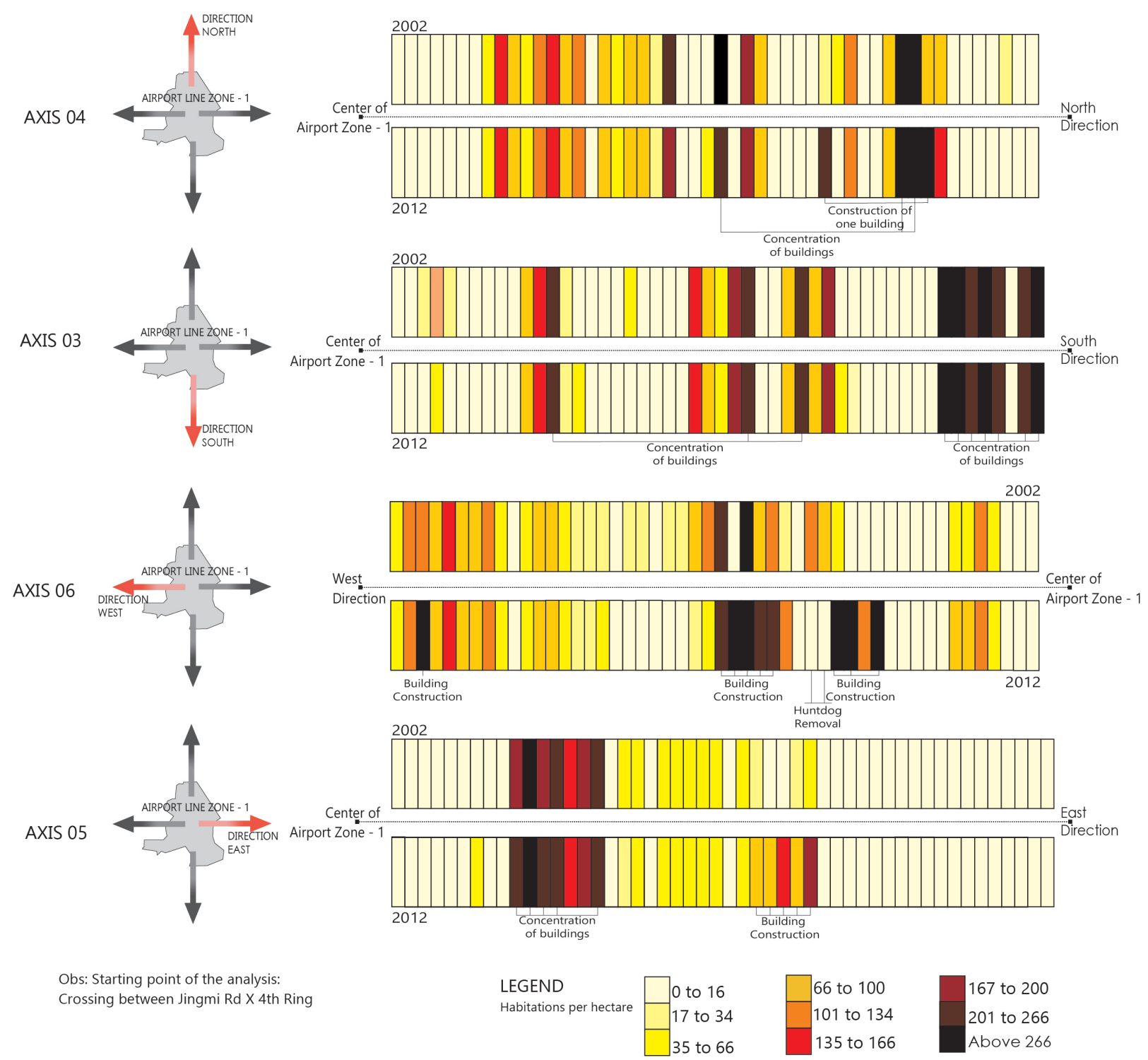

Figure 7 - Axes of the Airport Line Zone-1 SEZ in 2002 and 2012

Source: author, 2013, and Google Earth and Google Street View cartographic base.

In the northern portion of axis 8, belonging to Airport - 2 SEZ, there was no increase from 2002 to 2012 due to the distance from the central areas and the proximity to an area with a more rugged relief. On axis 7 (east of Airport Zone - 2) buildings were constructed close to the center of this compartment, demonstrating that this SEZ attracted a significant population in that direction by demolishing old hutongs and building residential buildings. 

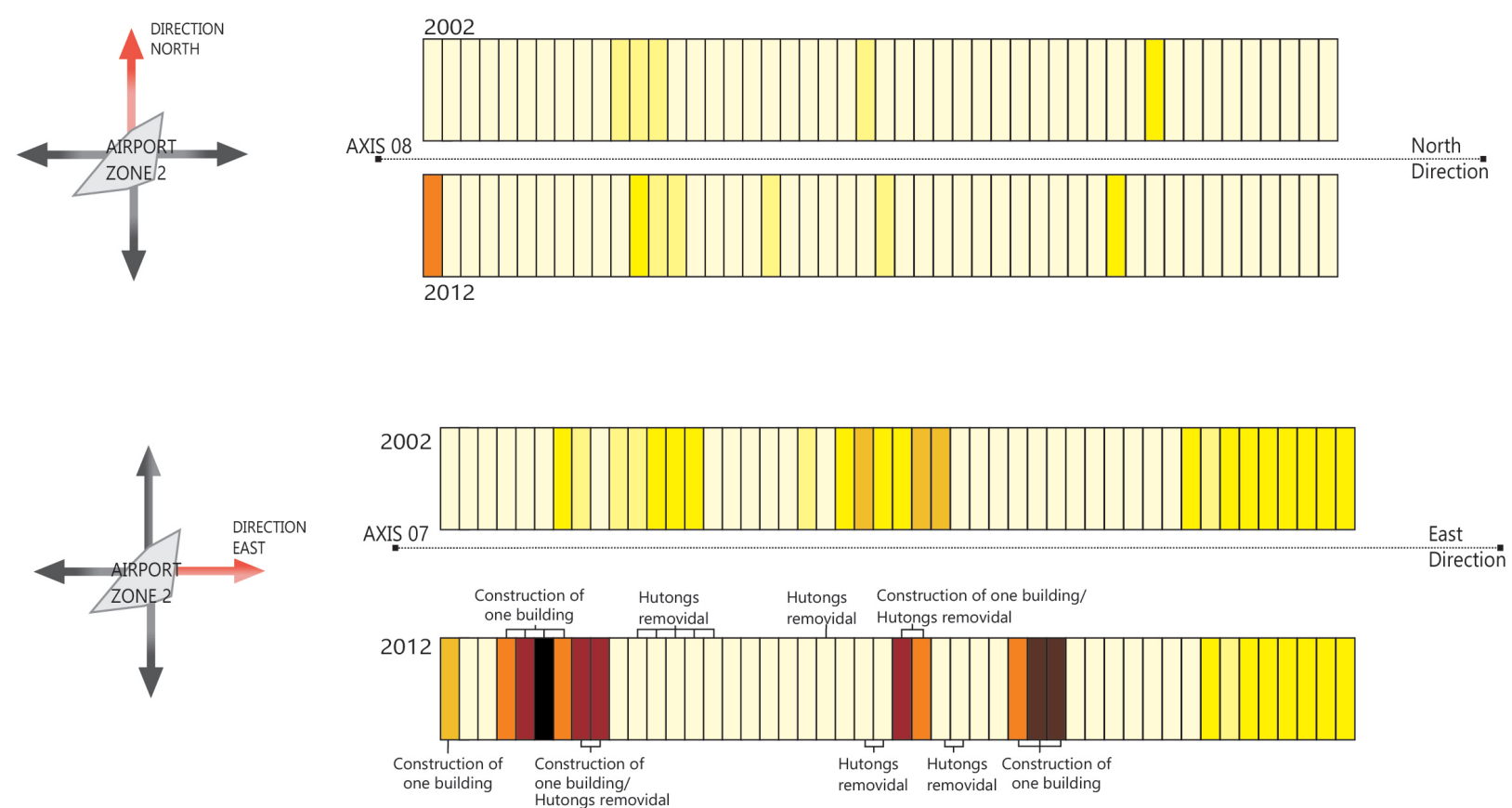

Obs: Starting point of the analysis:

Crossing between North St X Beixiache River

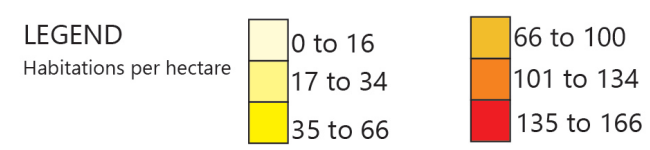

167 to 200 201 to 266 Above 266

Figure 8 - Axes of the Airport Line Zone-2 SEZ in 2002 and 2012 Source: author, 2013, and Google Earth and Google Street View cartographic base.

The use of CBD land is subdivided into mixed uses in the following proportions: $50 \%$ for offices, $25 \%$ residential apartments and $25 \%$ for consumption, leisure and entertainment (Greco and Santoro, 2007, p.142). It is important to clarify that the areas identified in this analysis correspond to the $25 \%$ destined to residential occupation. Light-colored squares do not mean that they are sparsely occupied, but that they have a low residental population. The area may have a dense use by corporate buildings, the characteristic predominant use in this compartment.

In 2002, the southern axis of the CBD (10) had a significant residential density at its extremes due to an intended connection with the port city of Tianjing. However, after the delimitation of the CBD, the high densities extended towards the center of this compartment, which indicates a process of consolidation of this centrality. In the vicinity of subway line 1, the residential density is low because historically commercial use has predominated.

With respect to the template, a central nucleus was determined with buildings 150 to 300 meters high that gradually reduced to 80 meters near the limits of the zone (Greco; Santoro, 2007, p.142). This may be the justification for axis 9 (east of the CBD) having significant densification in the center of the compartment in 2012, which reduces as it approaches the compartment boundaries.

However, Greco and Santoro (2007) explain that in the last decade, there has been a closer relationship between the $\mathrm{CBD}$ and the peripheral manufacturing areas, which may have encouraged the increase in the density of the extremities of the zone, dissimilar to the preestablished parameters.

Axis 9 has great importance for the city, as it is characterized as the main east-west road. The transformation of this portion occurred with the demolition of extensive areas of hutongs that were replaced by residential skyscrapers.

Axis 14 (south of Salitun) is directed towards the CBD, which is why there is a marked increase in density at its southern end in 2012. In 2002 the built density of the Salitun SEZ was significant, but in 2012 the center of the compartment appears to have lost residents, becoming a more commercial area. Towards the west (axis 15), the central area of the city, the resident population remains dense and stable. 
The central area of the city, because it has historical buildings and areas considered worthy of preservation, tends to change proportionally less than other compartments in the process of consolidation. Both on the axis connecting with Olympic Green and on the west and south axes, it is possible to visualize the low residential density in the center of the compartment due to the presence of the Forbidden City. Unlike axis 15, that connects Sanlitun with the Historical Center, which shows significant density as it approaches the center of the compartment. In the southern axes, one can see the reduction in density from 2002 to 2012.
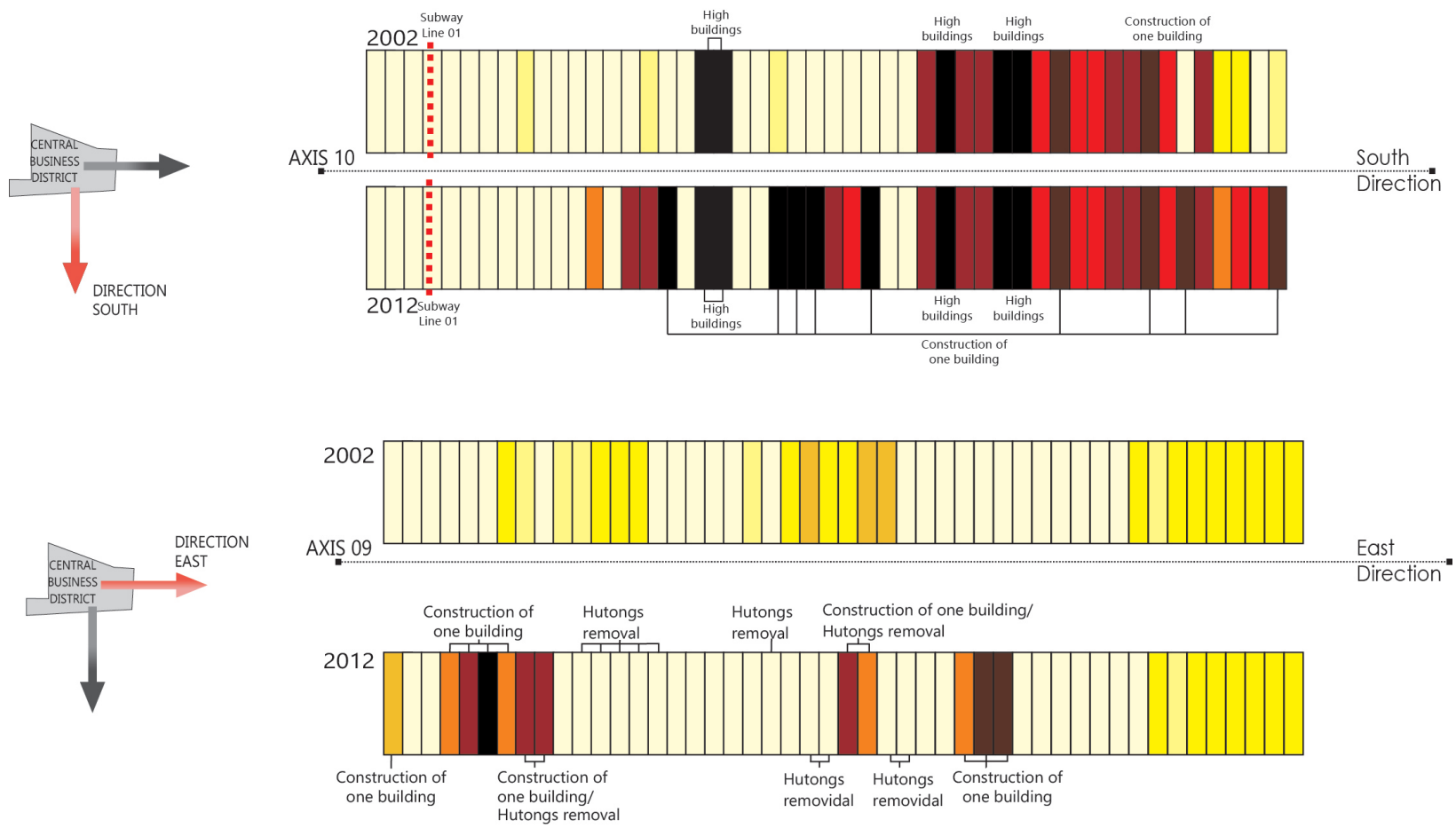

Obs: Starting point of the analysis

Crossing between Jianguomen Outer $X$ 3rd ring

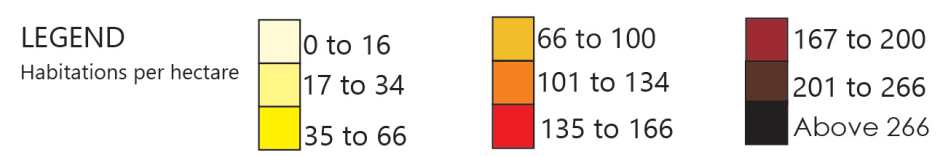

Figure 9 - Axes 09 and 10 of the CBD SEZ in 2002 and 2012

Source: author, 2013, and Google Earth and Google Street View cartographic base. 

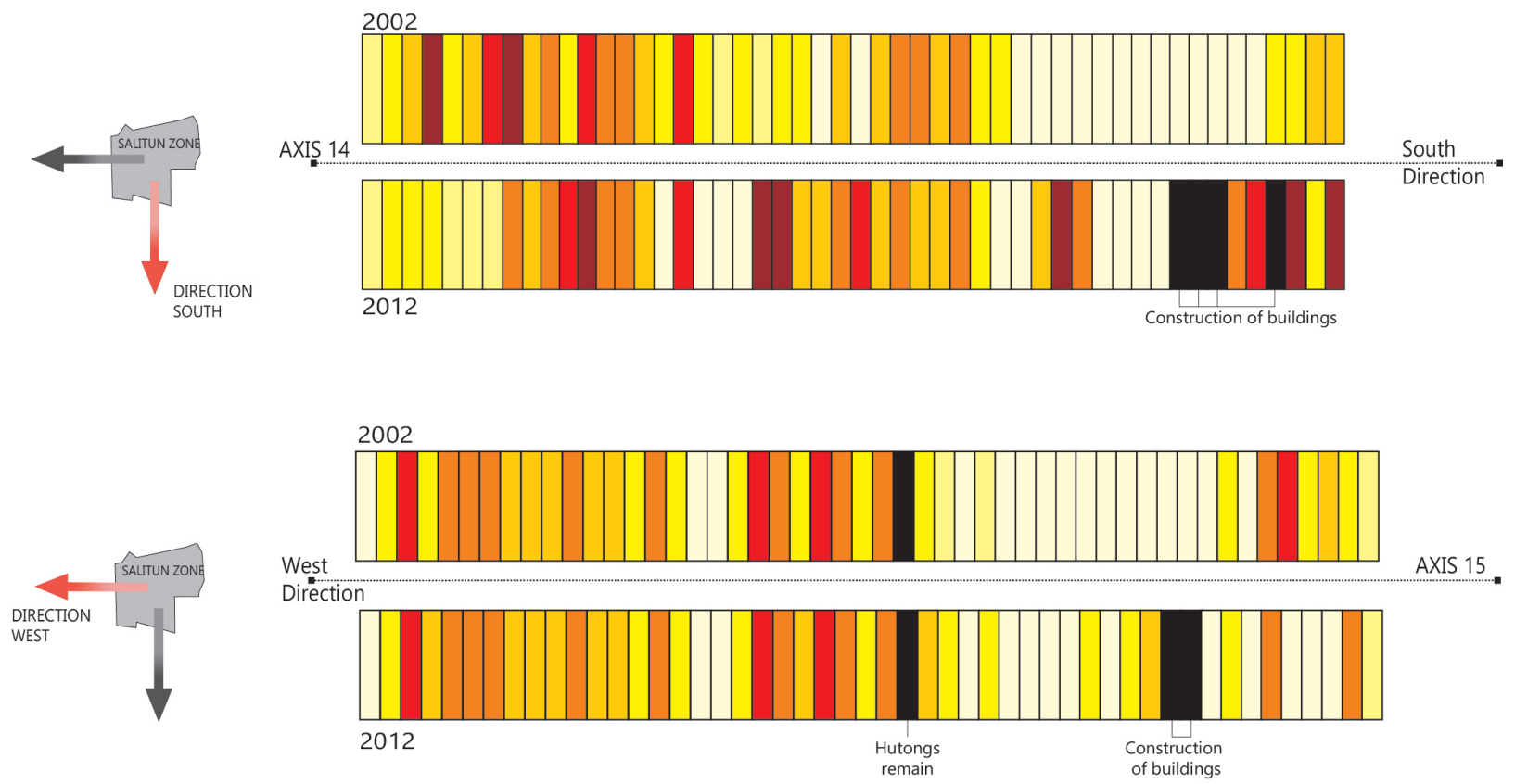

Jbs: Starting point of the analysis: zrossing between Dongsishitiao < Dongdaqiao Rd

$$
\begin{array}{l|l|l}
\text { LEGEND } & \text { Habitations per hectare } & \begin{array}{l}
0 \text { to } 16 \\
17 \text { to } 34 \\
35 \text { to } 66
\end{array}
\end{array} \quad \begin{aligned}
& 66 \text { to } 100 \\
& 101 \text { to } 134 \\
& 135 \text { to } 166
\end{aligned}
$$

Figure 10 - Axes 14 and 15 of the Salitun Zone in 2002 and 2012 Source: author, 2013, and Google Earth and Google Street View cartographic base.
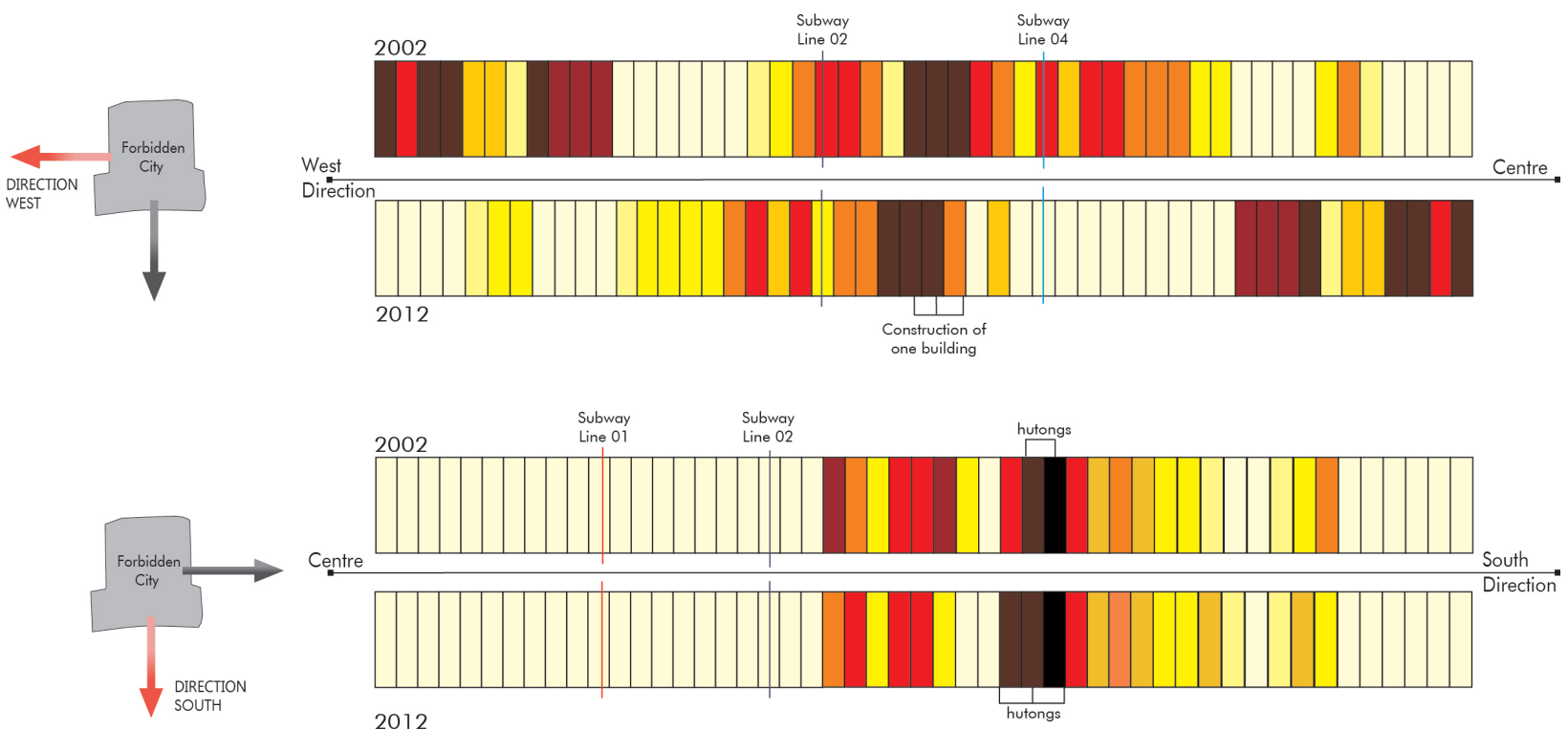

Obs: Starting point of the analysis: Centre of Forbidden City

$$
\begin{array}{l|l|l}
\text { LEGEND } \\
\text { Habitations per hectare }
\end{array} \quad \begin{aligned}
& 0 \text { to } 16 \\
& 17 \text { to } 34 \\
& 35 \text { to } 66
\end{aligned} \quad \square \begin{aligned}
& 66 \text { to } 100 \\
& 101 \text { to } 134 \\
& 135 \text { to } 166
\end{aligned}
$$

Figure 11 - Axes 01 and 02 of the Historical Center SEZ in 2002 and 2012 Source: author, 2013, and Google Earth and Google Street View cartographic base. 


\section{FINAL CONSIDERATIONS}

The 2004 Master Plan was designed to reinforce the intentions to spatially decentralize the city, carried out since the 1990s. The event served as an opportunity to justify once more the concentration of investments in the Chinese capital, with the claim of publicizing the country.

The Olympic Green, established as an SEZ, was only part of the planning for the city. Different from the others, which made it possible to set up businesses and trade and service activities that would encourage the vivacity of these areas, the Olympic Park was a space for tourists, with large structures that generated high maintenance costs and that are idle. The analysis of constructed housing density shows few significant changes from 2002 to 2012.

In terms of macro-planning, Beijing is consolidated in line with the intention to position the eastern portion for industrial production. The constructed densities show that there is a tendency of population densification in this direction, verified in 2012 by the compartments CBD, Olympic Green and Salitun SEZs. It is also possible to verify new areas of density in the areas near the Airport Zone 1 and 2 SEZs.

The two zones that most attracted a residential population and that are in the process of consolidation as centralities are the CBD and Salitun. Both lose out in attractiveness to the central area, as verified by the high densities in the western portions of these compartments, demonstrating their relevance as polarizing centers. However, in the eastern portion, the densities decrease as they move away from the centers of their compartments. The plan to transform SEZs into multi-use sites seems to be consolidating in these two compartments, since despite the presence of central areas focused on trade and services, a significant presence of housing is observed.

Therefore, the productive and environmental axes established by the plan have been consolidated, since the eastern and southern portions are the denser ones.

One relevant factor that contributes to the polycentric configuration is the cultural aspect that makes this type of occupation natural in Chinese society. Jun and Xiaoming (2008, p.21) call it self-centered urbanism or micro-society. Each part of the city that contains a centrality becomes an autonomous unit within another, which is called a fractal. They are the legacy of the rural areas (damwei), where the towns were composed of closed and economically self-sustaining communities. They can be on different scales such as ViCs, closed horizontal and vertical condominiums and siheyuans. Hassenpflug (2010, p.144) discusses the interrelation between physical and social space: communities, unlike society, are only spatialized in closed, private, introverted environments, expressed in places such as the backyard, which presupposes closeness and intimacy. This form of appropriation of spaces greatly facilitated the acceptance of SEZs by the population.

The justification for adopting this policy is that, if they were just productive sites, they would empty at night, like the American CBDs. Therefore, in Beijing, people residing and working in these SEZs keeps the space in operation 24 hours a day.

The scale of Beijing, both in area and in population, requires several centralities, since the monocentric structure has caused the delay or the paralization of flows in the central area. The establishment of new centralities can guide the urban expansion and land occupation that has occurred in a disorderly way.

In the analysis of the changes in population density, only residential use was counted, since it was the one that would better indicate the consolidation of the polycentric structure. According to Williams (2000, p. 34), if the population does not reside and only works in an area, the benefits of reducing the circulation of journeys in individual vehicles are lost.

In spite of measuring the changes that took place in the host cities of the Olympic Games, it was not possible to demarcate if their occurrence is directly related to the event. Poynter (2008, p. 123) argues that evaluating the effects of mega-events such as the Olympic Games is a complex task, as the social costs and benefits for the host city are difficult to estimate. 


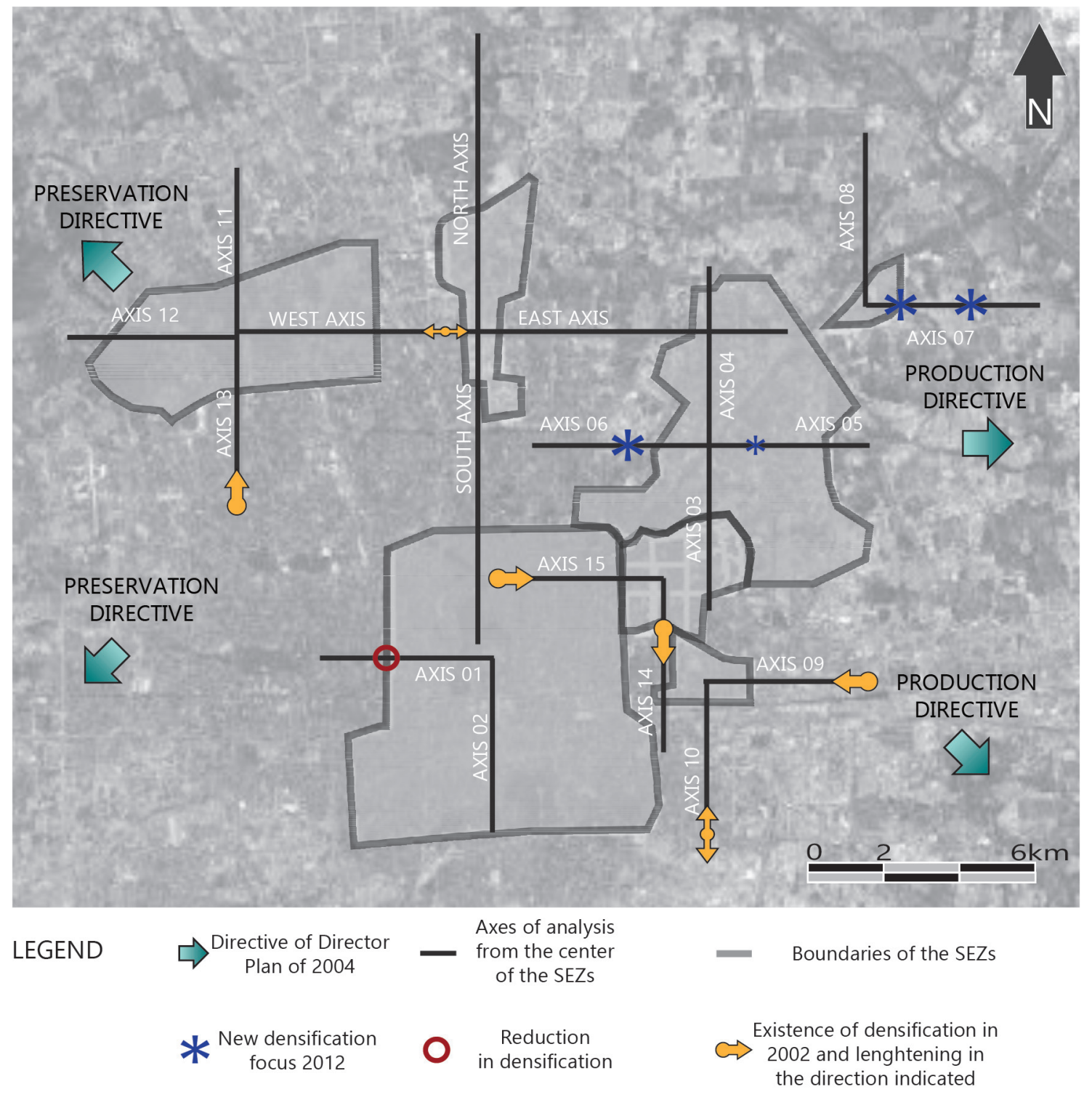

Obs: the size of the icons indicates the intensity of densification.

Figure 12 - Scheme of analysis of the densification trends from 2002 to 2012

Source: author, 2013, and Google Earth and Google Street View cartographic base.

The city that remains needs to be considered to produce positive effects and is associated with social, economic and political factors. According to Holland (2011, p.24), "without recognizing conventions there is no complete reading of the meaning nor of the configurational implications". Therefore, these planning intentions need to be analyzed in the local context; for this reason, the past city and cultural aspects need to be considered.

The plan elaborated for the Olympic Games is in line with the search for high-density occupations, mixed uses and intensification, which according to Burton (2000, p. 20) means a process of densification of the consolidated areas.

Thus, Beijing had a planning proposal with specific spatial and political objectives not directly related to the event. This characteristic can be considered positive and the main approximation to the experience of Barcelona, considered an example of success. In a context of political repositioning after the end of the dictatorship in the country, Barcelona intended to expose its differences in relation to the Castilians and to acquire economic autonomy, with separatist aspirations. To this 
end, it developed a set of urban interventions that recovered degraded areas and transformed them into new centralities with the objective of attracting international interest.

It is not possible to say that the result of city planning is considered the legacy of the Olympic Games. This would assign a degree of importance greater than the event actually has to a space that naturally changes constantly.

However, without the elaboration of a plan that benefits the city and that is only concerned with the perfect accomplishment of the event, there is no possibility of a legacy.

\section{BIBLIOGRAPHIC REFERENCE}

BURTON, Elisabeth. The compact city: just or just compact? A preliminary analysis. Urban Studies, Glasgow, v.37, n. 11, out. p.1969-2006, 2000.

HASSENPFLUG, D. The urban code of China. Basel: Birkhauser, 2010.

HUANG, Chongqing. China property market: Beijing property market watch. My Decker Capital, Beijing, jul. 2011.

DENG, Fredric F.; HUANG, Youkin. Uneven land reform and urban sprawl in China: the case of Beijing. Elsevier Progress in planning, v.61, p.211-236, 2003.

ESSEX, Stephen; CHALKLEY, Brian. Urban transformation for hosting the Olympic Games. Barcelona: Centre d'Etudis Olimpics (UAB), 2003. Disponível em: < http//olimpicstudies.uab.es/lecture/web/pdf/essex. pdf > Acesso em: jan. 2012.

FRIEDMANN, John. China's urban transition. Minneapolis: University of Minnesota Press, 2005.

GAUBATZ, Piper. China's urban trasnformation: patterns and process of morphological change in Beijing, Shangai and Guangzhou. Urban Studies, Thousand Oaks, v. 36, n. 9, p. 1945-1521, 1999.

GRECO, Claudio.; SANTORO, Carlo. Beijing: The new city. Milano: Skira editore, 2007.

HASSENPFLUG, Dieter. The urban code of China. Basel: Birkhauser, 2010.

HOLANDA, Frederico. A determinação negativa do movimento moderno. In: HOLANDA, F. (Org.) Arquitetura \& Urbanidade. 2 ed. Brasília: FRBH Edições, 2011.

JUN, Jiang.; XIAOMING, Kuang. The taxonomy of contemporary Chinese cities (we make cities): a sampling. . AD New Urban China, London, v. 78, n. 5, p. 16-21, 2008.

OJIMA, Ricardo. Dimensões da urbanização dispersa e proposta metodológica para estudos comparativos: uma abordagem socioespacial em aglomerações urbanas brasileiras. Revista Brasileira de Estudos de População, São Paulo, v.24, n.2, jul./dez. 2007.

PITTS, Adrian.; LIAO, Hanwen. Sustainable Olympic design and urban development. London: Routledge, 2009.

POYNTER, Gavin. 2008. Regeneração urbana e legado olímpico de Londres 2012. In: Rodrigues, R. P. et al. (Orgs.) Legado de megaeventos esportivos. Brasília: Ministério dos Esportes, 2008. p. 121-152.

PREUSS, Holger. Aspectos Sociais dos Megaeventos Esportivos. In: RUBIO, K. (Org.). Megaeventos esportivos, legado e responsabilidade social. São Paulo: Casa do Psicólogo, 2008. p. 13-35.

SONG, Yan; DING, Chengri; KNAAP, Ronald G. Envisioning Beijing 2020 through sketches of urban scenarios. Habitat International, v.30, p. 1018 -1034, 2006. Disponível em: <http://www.elsevier.com/ locate/habitatint >. Acesso em: 27 mar. 2010.

THOMPSON, John. B. A mídia e a modernidade: uma teoria social da mídia. Petrópolis: Vozes, 1998.

TORRENS, Paul. M.; ALBERTI, Marina. Measuring sprawl. London: Centre for Advanced Spatial Analysis - University College London, 2000.

WANG, Jun. Beijing Record: a physical and political history of planning modern Beijing. Singapore: World Scientific Publishing CO, 2011.

WILLIAMS, Katie; BURTON, Elisabeth; JENKS Mike. Achieving Sustainable Urban Form: an introduction. Londres: E \& FN Spon, 2000. 
YAN, Meng. Urban Villages. AD New Urban China, London, v.78, n.5. p.56-59, 2008.

YUKATA, Hirako et al. Beijing Hutong Conservation Plan: The future of Old Beijing and the conflict between modernization and preservation. Tibet Heritage Fund. in cooperation with Beijing Tsinghua University, 2004. Disponível em : < http://www.tibetheritagefund.org/media/download/hutong_study.pdf > Acesso em fev. 2012. 